\title{
PRODUCTION PROCESS QUALITY AND ITS IMPROVEMENT
}

\begin{abstract}
As a rich source of substances which are necessary for proper development of body that meets energy needs, growth needs and control needs, bread represents one of basic food products of everyday diets that humans have used for many centuries. With increasing demands and expectations of customers, bakery and confectionery enterprises have to face the challenge of improving the quality of goods. This can be achieved with quality tools and methods. The use of these tools and methods allows for elimination of the identified inconsistencies in the product through determination of the causes of their occurrence and proposal of corrective activities. This study aims to indicated the most substantial quality defects in wheat challan through application of Pareto-Lorenz analysis. The Ishikawa diagram was prepared at the next stage. The diagram offers opportunities for indication of a solution that might contribute to liquidation of the quality defects found.
\end{abstract}

Keywords: quality, Pareto-Lorenz, Ishikawa diagram, bakery and confectionery goods.

\section{Introduction}

Continual improvement is an important principle of total quality management and also new quality management principle involved to the revised ISO 9000 family of standards, which were officially released on $15^{\text {th }}$ December 2000 (PLURA J. 2000, RoszaK M. 2016, SKRZYPEK E. 2010, SobCZYK G., CElOCH A. 2012, ZiEliŃSKi G., KRZESZEWSKA M. 2012).

Wheat challan is a type of semi-confectionery wheat bread without filling, baked from wheat flour with yeast with addition of sugar, fat, milk, eggs, salt and other raw materials according to a recipe with might involve the use of enhancers. The amount of sweeteners and fat in total should be not less than $15 \mathrm{~kg}$ per $100 \mathrm{~kg}$ of flour. The ingredients other than flour should represent $40 \%$ of all the ingredients (PN-A-74106: 1993, AMBROZIAKA Z. 1988).

Basic information about the decorative challah described in the study PN-A74106: 1993, AMBROZIAKA Z. 1988):

- Ingredients: flour, water, eggs, yeast, sugar, salt, milk, fat.

- Type of dough preparation: straight dough method.

- Method of chunk forming: manual

\footnotetext{
${ }^{1} \mathrm{PhD}$., Czestochowa University of Technology, Faculty of Management, Department of Production Engineering and Safety, e-mail: asros@op.pl
} 
- Additives: on the top: moisturised with egg paste or water, sprinkled with crumble topping (ROSZAK M., SPILKA M., KANIA A. 2015).

With the recipe used in the enterprise studied for production of the challah, individual stages of the technological process of the product analysed in the form of the block diagram of operations that occur during production and individual processes with their parameters (Fig. 1). Technological process is an integral part of this study since its analysis was of key importance to identification of the causes of discrepancies.

The technological process of production of decorative challah presented in Fig. 20.1 is a multi-stage complex production process. Its first stage (Preparation and dosage of ingredients) is presented in the form of several operations and individual processes which represent preparation activities before production of individual product ingredients. The process of Fermentation and dough puncturing was divided, according to the technology of manufacturing, into several successive activities ended with final fermentation. The stage of Baking of the product is presented in the form of three phases which differ in terms of temperature and other process parameter according to the technology used.

\section{Aim of the study and research methodology}

The examinations were carried out in one of the bakery and confectionery plants located in the Lower Silesia region. Their aim is to identify inconsistencies and defects at the stage of challah production as a result of an in-depth analysis of the technological process and the requirements defined for the challah contained in the PN-A-74106:1993 standard and determination of their causes and presentation of proposals for improvements in terms of quality and safety for production based on popular methods and tools of quality management. The Pareto-Lorenz chart and Ishikawa diagram were used in order to achieve the research goals (BORKOWSKI S., ROSAK-SZYROCKA J., ZATON A. 2011).

Pareto-Lorenz chart is a method that stems from the work of Italian economist and sociologist Vilfredo Pareto (Witkiewicz W., CymbaŁa V., FiaŁkowska M. 2012, BERWICK, D.M. 1989). This researcher discovered specific regularities through examination of the structure of properties of physical goods in society. He demonstrated that $80 \%$ of entire property in the country is owned by $20 \%$ of society (Hamrol A. 2008, Piekara A., Dziuba S. T., Kopec B. 2012, Dziuba S.T., Godyń M. 2014, BORKOWSKI S., INGALDI M., JAGUSIAK-KOCIK M. 2014). 


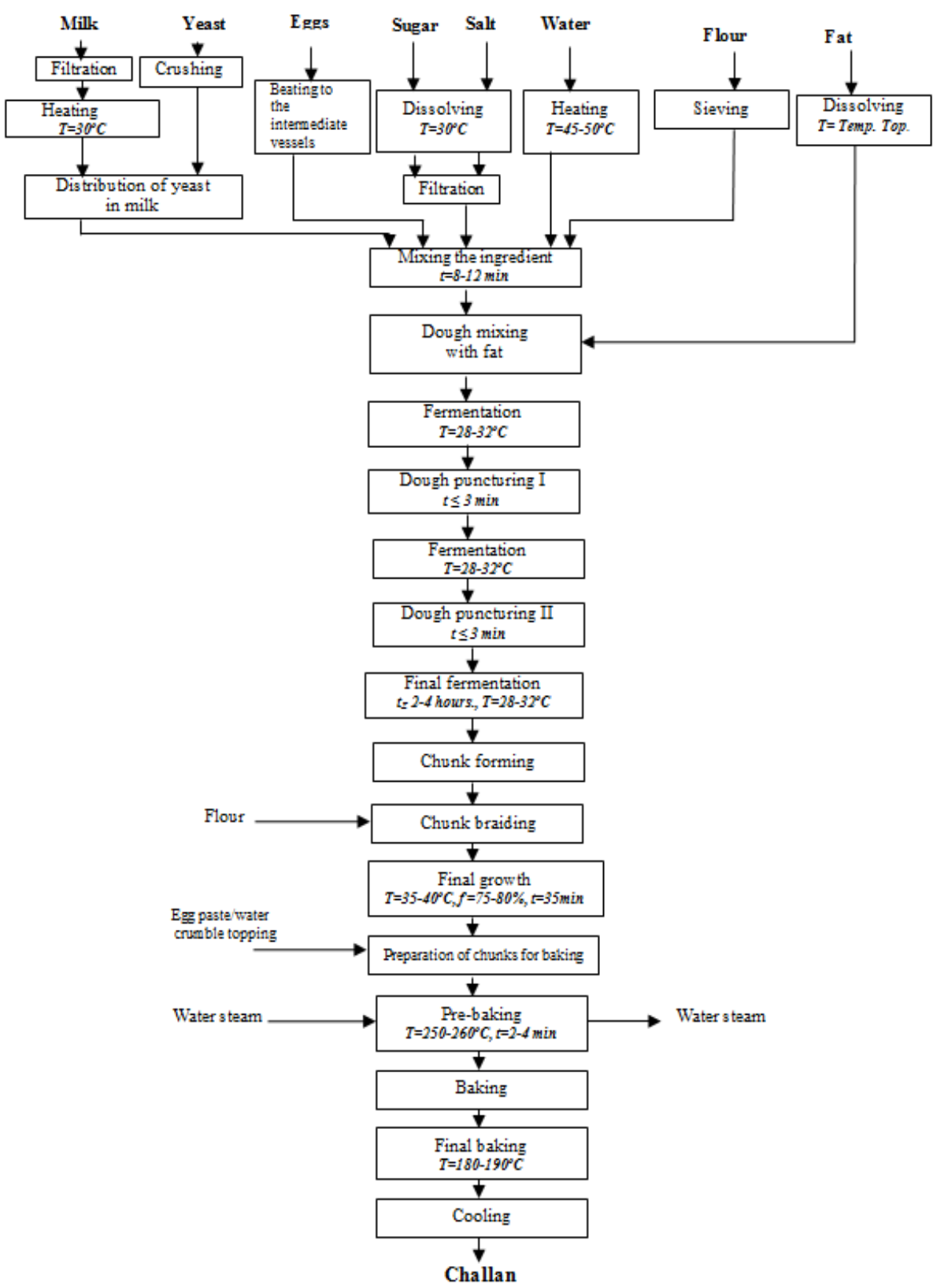

Fig. 1. Block diagram of the technological process of production of wheat challan. Source: own study 
This led to the definition of the $80 / 20$ principle which says that $80 \%$ of the effects results from only $20 \%$ of causes. In other words, there is an internal balance between the effort and the effects. The most of the efforts do not lead to the outcomes assumed and very few of the factors have an effect on actually significant results. Furthermore, Pareto presented the statistical data in a graphical form using a chart that showed population's incomes in specific ranges. Similar charts were obtained by another Russian researcher, M.O. Lorenz, who examined distribution of wealth. However, the difference was in the approach to the results: Lorenz curve did not reveal percentage distribution in individual groups but it showed accumulated percentage shares (Hamrol A. 2008, Piekara A., DziUba S. T., Kopec B. 2012, DziUba S.T., GodyŃ M. 2014).

As a result of presentation of the two diagrams in one figure, the form of ParetoLorenz chart was obtained, which has been used until today, based on empirically found principle which says that usually $20 \%$ to $30 \%$ of causes (factors) prodocue ca. 80\%-70\% outcomes(Hamrol A. 2008, PieKara A., DziUba S. T., KoPeC B. 2012, DZIUBA S.T., GodYŃ M. 2014).

Ishikawa diagram allows for determination of the causes of the defects and inconsistencies and their mutual relationships using the most basic graphical form of a diagram. The cause-and-effect diagram, which is another name for the Ishikawa diagram, is used to recognize the causes of various phenomena i.e. defects and other inconsistencies that occur in e.g. production processes. The aim of the Ishikawa method is to find the places of defects, its elimination and taking appropriate measures to prevent from their occurrence in the future. The characteristics of the cause-andeffect diagram include in particular the opportunities for discovery of unexposed relationships between individual causes, the method of recording the ideas and the use of the brainstorming method (HAMrol A. 2008, PieKara A., DZiUba S. T., KoPEC B. 2012, BORKOWSKI S., INGALDI M., JAGUSIAK-KOCIK M. 2014).

\section{Classification of quality inconsistencies using the Pareto-Lorenz diagram}

After analysis of the technological process in the bakery-confectionery enterprise analysed in the study, with control examinations of final goods and collection of the data, the number of all the defects and discrepancies were summed and the order of the defects was determined in terms of the frequency of their occurrence. Furthermore, the percentage share and accumulated percentage values were calculated for each defect (see Tab. 1). 
Based on the data contained in Table 1, the Pareto-Lorenz chart was prepared to reflect the share of individual quality defects of the challah (Pareto bars) and accumulated values (Lorenz curve), which was demonstrated in Fig. 2.

Fig. 2 shows that the defects 1 and 2 (improper taste and sticky, slack-backed and undercooked breadcrumb) represent in total $80 \%$ of all the quality defects of the challah. In order to ensure the substantial improvement in the quality of the product, the focus should be on the two indicated defects and the causes of these defects.

Table 1. Discrepancies according to the frequency of occurrence

\begin{tabular}{|l|c|c|c|c|}
\hline \multicolumn{1}{|c|}{ Defect } & $\begin{array}{c}\text { Number } \\
\text { of } \\
\text { defects }\end{array}$ & $\begin{array}{c}\text { Accumulated } \\
\text { number of } \\
\text { defects }\end{array}$ & $\begin{array}{c}\text { Relative } \\
\text { frequency of } \\
\text { defects } \\
\text { \%) }\end{array}$ & $\begin{array}{c}\text { Accumulated } \\
\text { relative } \\
\text { frequency of } \\
\text { defects (\%) }\end{array}$ \\
\hline 1. Improper taste & 50 & 50 & 50 & 50 \\
\hline $\begin{array}{l}\text { 2. Sticky, undercooked breadcrumb, } \\
\text { slack-baked }\end{array}$ & 30 & 80 & 30 & 80 \\
\hline 3. Deformed shape & 5 & 85 & 5 & 85 \\
\hline 4. Improper smell & 4 & 89 & 4 & 89 \\
\hline 5. Improper colour of the crest & 3 & 92 & 3 & 92 \\
\hline 6. Mechanical defects & 2 & 94 & 2 & 94 \\
\hline $\begin{array}{l}\text { 7. Crest that separates from the } \\
\text { breadcrumb }\end{array}$ & 2 & 96 & 2 & 96 \\
\hline 8. Crest dirty or burned & 2 & 98 & 2 & 98 \\
\hline $\begin{array}{l}\text { 9. Crest with marks of mould and } \\
\text { symptoms of infection with Bacillus } \\
\text { mesentericus }{ }^{1}\end{array}$ & 1 & 99 & 1 & 99 \\
\hline 10. Inelastic breadcrumb with big pores & 1 & 100 & 1 & 100 \\
\hline
\end{tabular}

1) this bacteria manifests in changes in the texture of the breadcrumb, taste, smell and look of the bread

Source: own study 


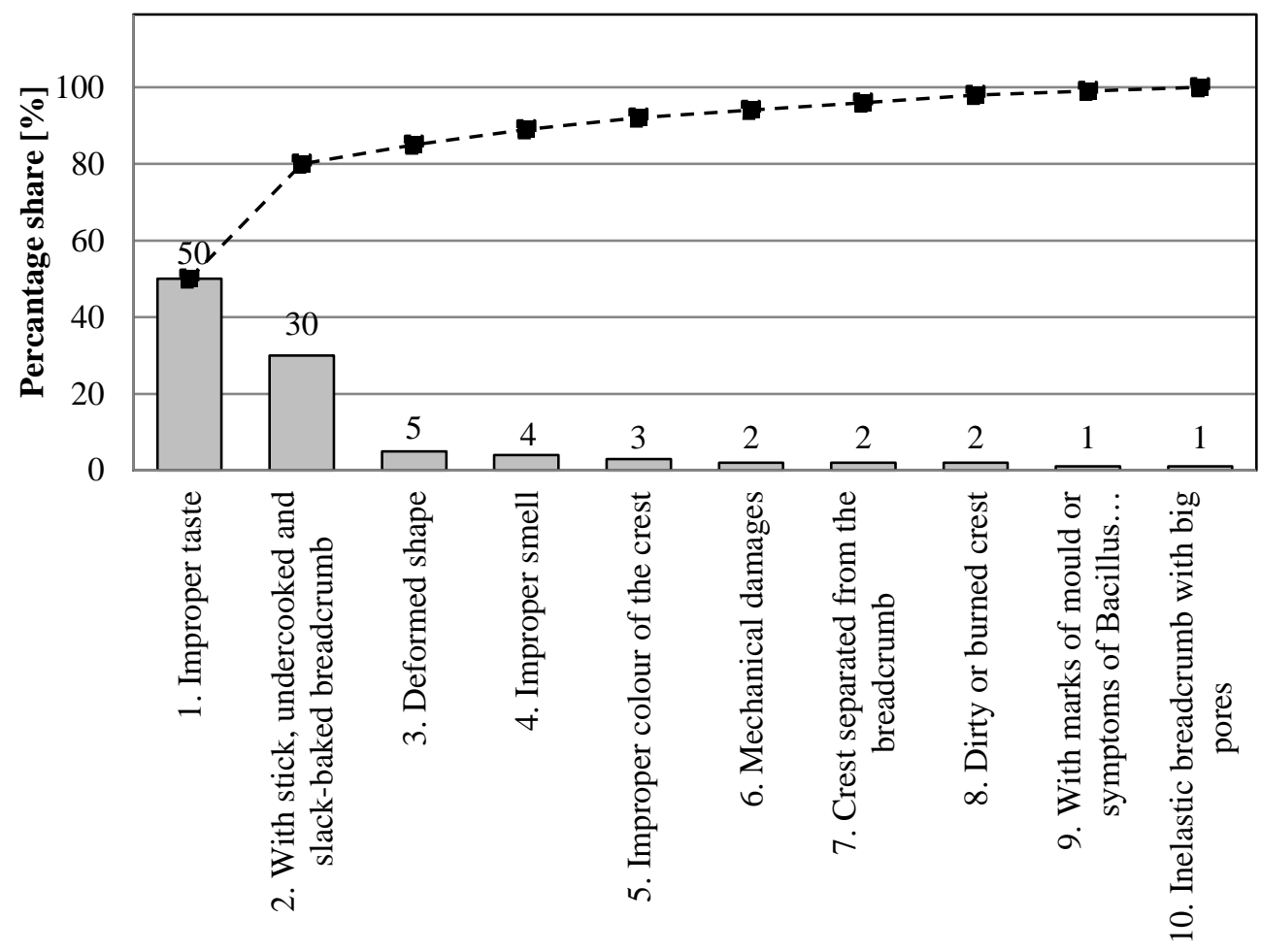

Fig. 2 Pareto-Lorenz chart for wheat challah.

Source: own study

\section{Analysis of the causes of defects based on the Ishikawa diagram}

In order to eliminate the most essential defects which were determined using Pareto-Lorenz chart (see Tab. 1 and Fig. 2), one should determine the causes of their occurrence. These activities are possible using the Ishikawa diagram. This tool allows for identification of the sources of the defects. Ishikawa diagram presents graphical relationships between the factors that have an effect on the defects analysed and causes of their occurrence.

Figs. 3 and 4 present the cause-and-effect for the defect "improper taste" and "sticky, undercooked breadcrumb, slack-baked" that occurred in the challah. 


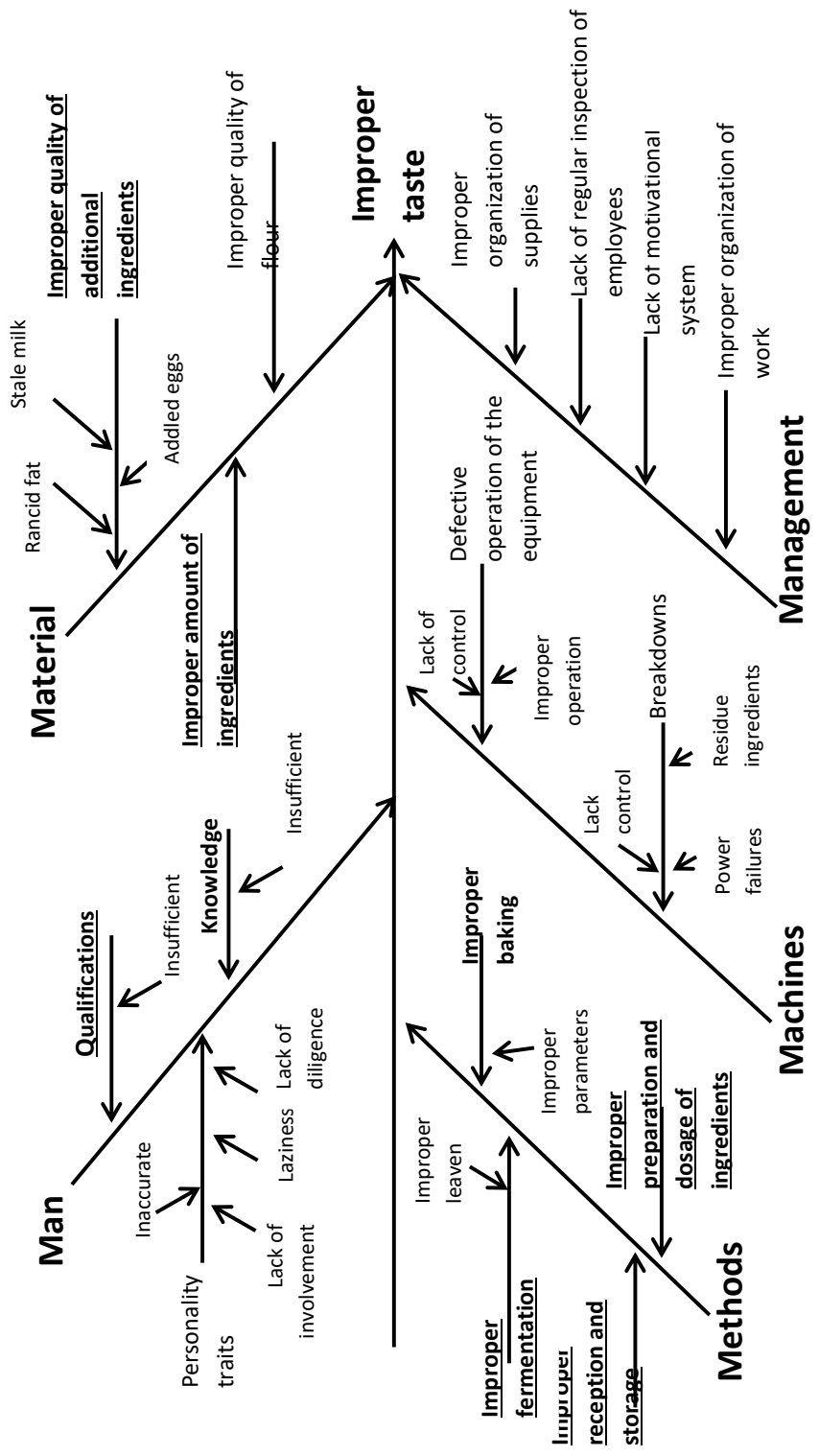

Fig. 3. Ishikawa diagram for the defect "improper taste". 


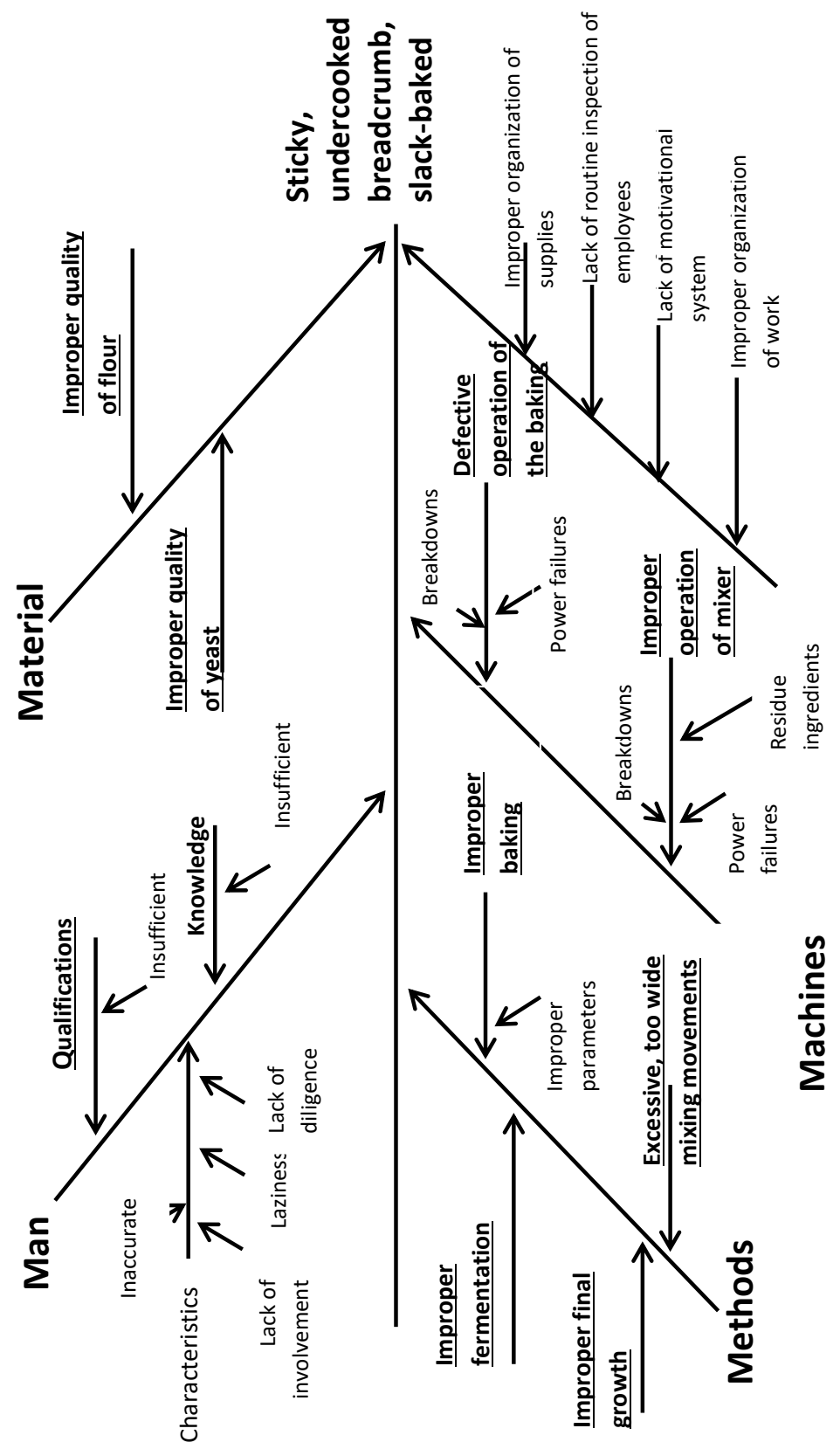

Fig. 4. Ishikawa diagram for the ueject "sticky, undercooked breadcrumb, slack-baked". Source: own study 
Fig. 3 reveals that the main causes that result in the quality defect of the challah of "improper taste" include:

- improper quality of additional ingredients,

- improper amount of ingredients,

- employee competencies,

- improper fermentation,

- improper reception and storage,

- improper baking,

- improper preparation and dosage of ingredients.

In the case of the second defect (Fig. 4), i.e. ,sticky, undercooked breadcrumb, slack-baked", the causes can be found in:

- improper quality of flour,

- improper quality of yeast,

- employee competencies,

- improper fermentation,

- improper final growth,

- improper baking,

- improper mixing,

- defective equipment.

The analysis revealed that the most of the causes that result in "improper taste" and "sticky, undercooked breadcrumb, slack-backed" can be mainly found in improper methods, materials and machines. Therefore, quality-oriented measures should be taken in these areas.

\section{Conclusions}

In times of fierce competition and increasing awareness of consumers, enterprises that want to generate profits have to ensure the safety and proper quality of their products.

In order to adjust products to customer requirements, a wide range of tools and methods are used to allow for identification and elimination of defect that are generated across the production process. Removing these defects improves the quality of the final product, thus increasing consumers' trust in the quality of the products.

With quality tools used in this study, it was demonstrated that quality defects were caused at individual stages of the process of production of wheat challah, grouped in the Ishikawa diagram in materials, methods and machines. In order to eliminate the most important causes of defects, one should take corrective measures aimed at improvement in the quality of the final product. Such measures include: 
- verification of technological parameters with accurate description in transparent and legible instructions,

- determination of the new criteria of supply in ingredients through modification of specifications in commercial contacts combined with verification of suppliers,

- maintenance of production machines and equipment connected with checking their proper operation by an everyday user. Appointment of the employees responsible for regular inspections and maintenance works according to the internal schedule that determines its scope and aim contribute to maintaining adequate performance of machines and equipment that directly affect the quality of the final product.

- investments in additional training, motivational programmes in various forms which represent the well-proved method to improve the quality of work.

Financial outlays connected with the changes proposed will positively return in the future and will help eliminate the defects.

\section{Bibliography}

1. AmbroziaKa Z. 1988. Piekarstwo i ciastkarstwo.Wydawnictwo Naukowo-Techniczne, Warsaw.

2. BERWICK D.M. 1989. Continuous improvement as an ideal in health care. New England Journal Medicine, (320): 53-56.

3. BoRKOWSKI S., INGALDI M., JAGUSIAK-KocIK M. 2014. Struktura niezgodności i ważność rodzajów kontroli wizualnej podczas produkcji opakowań szklanych. [W:] Systemy Wspomagania w Inżynierii Produkcji. Jakość i Bezpieczeństwo. Red. Jacek Sitko, Bartosz Szczęśniak. PA NOVA SA, Gliwice.

4. Borkowski S., RosAK-SZYROCKA J., ZATON A. 2011. Identification Processes Requiring the Improvement. Yurii V. Makovetsky. Dnipropetrovsk.

5. DZIUBA S.T., GODYŃ M. 2014. Identification of significant discrepancies occurring in the process of cable production using selected quality management tools. [In:] S. BORKOWSKI, M. InGALDI, Toyotarity. Management of Technology, Chapter 12. Aeternitas Publishing House, Alba Iulia, Romania.

6. DziUba S.T., Piekara A., MaŁas W., KoziOł P. 2013. Traditional tools of quality improvement used to improve furniture production process. [In:] BORKOWSKI S., SYGUT P., Control Meaning in Products and Processes Improvement.

7. HAMROL A. 2008. Zarządzanie jakościa z przykładami. PWN, Warsaw.

8. PlURA J. 20000. Continual improvement within the quality management systems, KVALITA INOViCIA PROSPERITA IV/12000 (13 ñ 22).

9. PN-A-74106:1993 STANDARD: SEMI-CONFECTIONERY WHEAT BREAD, PKN. Warsaw 1993. 
10. RoszaK M. 2016. Zarzadzanie Wiedza Jako Czynnik Ksztattujacy Wartość Dodanq Organizacji. Rosak-Szyrocka J., Sokół A., Roszak M. (Red.). Materialne i niematerialne źródła tworzenia wartości - wybrane zagadnienia z zarządzania i ekonomii, Celje, Faculty Of Logistics, University Of Maribor, ISBN 978-961-6562-74-4, s. 140.

11. RoszaK M., SPILKA M., KANIA A. 2015. Environmental failure mode and effects analysis (FMEA) - a new approach to methodology. Hrvatsko Metalursko Društvo (HMD). Metalurgija. T. 54, Wyd. 2, p. 449-451.

12. SKRZYPEK E. 2010. Doskonalenie jakości jako szansa na sukces organizacji. Współczesne Zarządzanie nr 3, Kwartalnik Środowisk Naukowych i Liderów Biznesu, s. 42-50.

13. SobCZYK G., Celoch A. 2012. Wspótczesny marketing. Skuteczna komunikacja $i$ promocja. Filar A. (Red.), UMCS.

14. WitkieWicz W., CymbaŁa V., FiaŁKOwSKA M. 2012. Możliwość wykorzystania prostych narzędzi poprawy jakości opartych na filozofii kaizen przy wdrożeniu Okołooperacyjnej Karty Kontrolnej. XVI Ogólnopolska Konferencja Jakość w Opiece Zdrowotnej, Centrum Monitorowania Jakości w Ochronie Zdrowia, The ability to use simple Kaizen-based quality improvement tools in the implementation of the Operational Control Card, the $16^{\text {th }}$ National Conference on Quality in Health Care, the Quality Monitoring Center for Health Care: $67-75$.

15. ZIELIŃSKI G., KRZESZEWSKA M. 2012. Doskonalenie jakości ustug poprzez wykorzystanie controllingu w obszarze logistyki w zakładach opieki zdrowotnej, „Zarządzanie i Finanse”, R. 10, nr 3, cz. 1 . 